\title{
Analytical Study of Corona Cases Examined at the Emergency Department in KHMC-RMS
}

\author{
Abdallah Mherat*, Ibrahim Abu Hussein, Issam AlRbeihat, Ashraf A Odeh and Shirin Al \\ Mharat \\ Royal Medical Services, Jordan
}

*Corresponding author: Abdallah Mherat, Royal Medical Services, Jordan

\begin{tabular}{|c|c|}
\hline ARTICLE INFO & ABSTRACT \\
\hline Received: October 27, 2020 & Introduction: Corona virus stars 2 , known as COVID-19, has come as an international \\
\hline Published: November 05, 2020 & $\begin{array}{l}\text { health problem since the late of } 2019 \text {. It has been recognized by the World Health } \\
\text { Organization (WHO) as COVID-19 pandemic. Jordan has established several clinics to }\end{array}$ \\
\hline
\end{tabular}

Citation: Abdallah M, Ibrahim Abu H, Issam A, Ashraf AO, Shirin Al M. Analytical Study of Corona Cases Examined at the Emergency Department in KHMC-RMS. Biomed J Sci \& Tech Res 31(4)-2020. BJSTR. MS.ID.005139.

Keywords: Corona; Emergency Department; Summer; March; August; COVID-19 Pandemic; PCR

Objectives: To analyze and report the results of existing data of patients who visited Corona clinic in the emergency department in Royal Medical Services, Jordan.

Methodology: A retrospective study design was conducted to collect data from files of patients who were examined in corona clinics in the emergency department in Royal Medical Services, Jordan. The following variables were considered: the total number of patients visiting the corona clinics per month, the number of suspected patients to be infected with corona virus per month, and the number of cases confirmed by PCR per month. Data were presented as tables and figures to show the variations in suspected and confirmed cases.

Study Findings: The present study showed that during the period between March and April, corona clinics received a total of 3416 patients of whom 2294 cases were suspected to have corona virus, and a total of 1122 cases were confirmed by PCR. Cases followed similar trends in the frequency of corona virus from March to July. In August and September, changes in trends occurred which may be due to the impact of media in which it was perceived that the COVID-19 pandemic is going to end during summer months due to increased temperature degrees.

Conclusions: the present study showed increasing incidence of corona cases during the study period from March-September.

\section{Introduction}

It has been more than fifty years since the principal disclosure of human Covid [1]. A progression of episodes and scourges of respiratory sicknesses have been ascribed to different sorts of these infections, for example, Severe Acute Respiratory Syndrome (SARS) and Middle East Respiratory Syndrome (MERS), which were brought about by SARS-CoV and MERS-CoV, individually, notwithstanding the current Covid Disease 2019 (COVID-19) [2]. Coronavirus is brought about by novel SARS-CoV-2, which, in a specific way, has genomic likenesses to MERS-CoV and SARS-CoV [3]. These Covid are sent from their creature beginnings to people through a middle host, for example, camels on account of MERS and civet felines on account of SARS [4]. Shockingly, the halfway host

that is liable for the interspecies (creature to human) transmission of the novel SARS-CoV-2 is as yet under discussion [2]; pangolins could be a potential up-and-comer [4], in any case, it is as yet far from being obviously true whether the essential starting point of the novel SARS-CoV-2 comes from bats or pangolins [2]. In late December 2019, pneumonia of an obscure reason was accounted for in Wuhan city, China, what is more, starting here of beginning, the flare-up has spread broadly to a worldwide scale [3]. On the 30th of January 2020, the WHO announced the episode of COVID-19 as a worldwide general wellbeing crisis, also, upon the exponential increment in the quantity of cases and nations influenced by the illness, Coronavirus was then announced as a pandemic on the 
eleventh of March 2020 [5,6]. The manifestations of COVID-19 generally show up inside 2-14 days of securing the infection, and a diverse scope of manifestations and seriousness can influence patients, including fever, dry hack, dyspnea, sore throat, sickness, spewing, the runs, myalgia, and exhaustion $[7,8]$.

Albeit most COVID19 patients build up a mellow level of side effects and show unconstrained recuperation, there is still an extent of patients, particularly more seasoned age bunches with basic comorbidities, that are at higher danger of building up a more serious disease that is related with confusions [5,7]. Within the mid of April 2020, more than 1.85 million individuals have been confirmed to have Covid sickness (COVID-19). Even though around 429,028 cases are as of now recouped, the loss of life came to more than 114,331 overall [9]. Most nations recorded variable paces of COVID-19 cases and passing's, inducing a noteworthy weight on their wellbeing frameworks. Subsequently, a portion of these public wellbeing frameworks imploded, lost control, and got incapable to give wellbeing administrations to countless COVID-19 cases and others out of luck [10].

\section{Study Objectives}

To analyze and report the results of existing data of patients who visited Corona clinic in the emergency department in Royal Medical Services, Jordan.

\section{Methods and Subjects}

\section{Study Design}

A retrospective study design was conducted to collect data from files of patients who were examined in corona clinics in the emergency department in Royal Medical Services, Jordan. The following variables were considered:

a) The total number of patients visiting the corona clinics per month. b) The number of suspected patients to be infected with corona virus per month.

c) The number of cases confirmed by PCR per month.

Data was presented as tables and figures to show the variations in suspected and confirmed cases.

\section{Results}

\section{Frequency of Visiting Patients to Corona Clinics}

As shown in Table 1 and Figure 1, the total number of patients visiting corona clinics in March was 302 patients, of whom 258 patients were suspected to have corona virus. A total of 44 cases were confirmed to have corona by PCR. By the end of April, the total number of patients increased three folds (970 patients), of whom there were 741 suspected cases. A total of 229 cases were confirmed by PCR. In May, there was a reduction in the total number of visiting patients to corona clinics (565 patients), of whom 380 patients were suspected, and 185 patients were confirmed by PCR. In June, further reduction in the total number of visiting patients to corona clinics (514 patients) among which were 260 suspected cases, and a total of 254 cases were confirmed by PCR. In July, more reduction in the number of total patients who visited corona clinics (218) among which were 110 suspected cases, and 108 cases were confirmed by PCR. In August, there was a sudden increase in the total number of visiting patients to corona clinics (576 patients) among which 369 suspected cases, and 207 confirmed cases by PCR. In September, there was a sudden reduction in the total number of visiting patients to corona clinics (271patients), of whom 176 patients were suspected to be infected with corona virus, and 95 cases were confirmed by PCR. Taken together, 3416 patients visited corona clinics in the emergency department in Royal Medical Services, Jordan, among which were 2294 suspected cases, and 1122 cases confirmed by PCR.

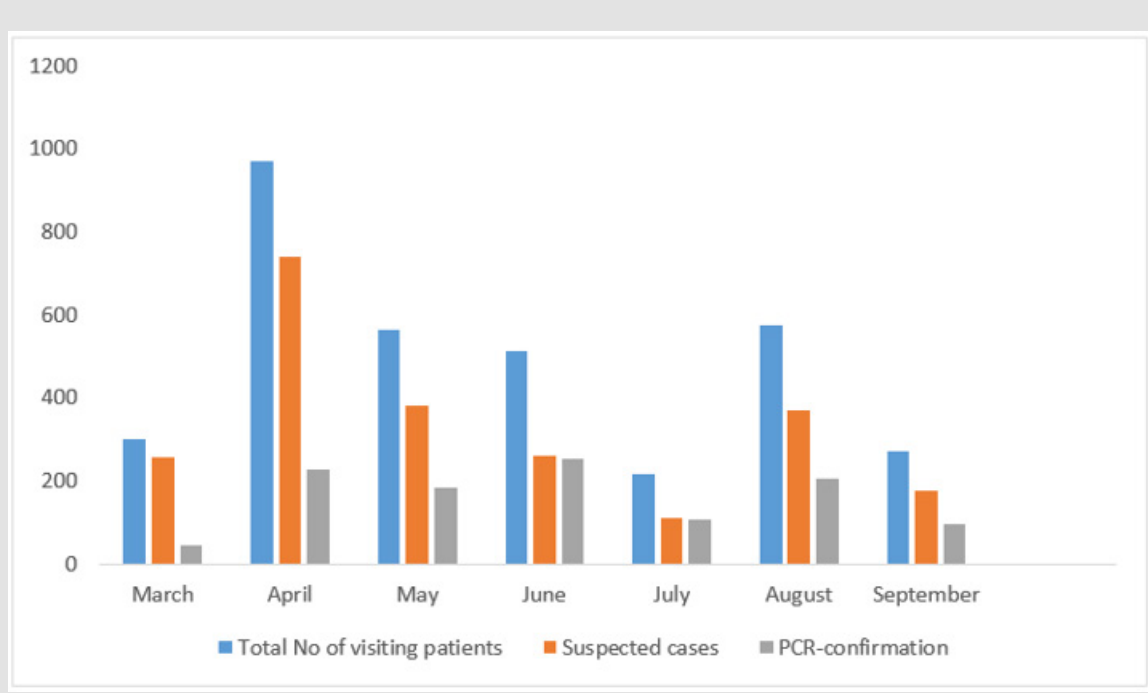

Figure 1: Frequency and distribution of patients who visited corona clinics (March to September 2020). 
Table 1: Frequency of visiting patients to corona clinics.

\begin{tabular}{|c|c|c|c|}
\hline Month & $\begin{array}{c}\text { Total No of patients visiting } \\
\text { corona clinics }\end{array}$ & No of suspected cases & No of cases confirmed by PCR \\
\hline March & 302 & 258 & 44 \\
\hline April & 970 & 741 & 229 \\
\hline May & 565 & 380 & 185 \\
\hline June & 514 & 260 & 254 \\
\hline July & 218 & 110 & 108 \\
\hline August & 576 & 369 & 207 \\
\hline September & 271 & 176 & 95 \\
\hline Total & 3416 & 2294 & 1122 \\
\hline
\end{tabular}

\section{Discussion}

The present study showed that during the period between March and April, corona clinics received a total of 3416 patients of whom 2294 cases were suspected to have corona virus, and a total of 1122 cases were confirmed by PCR (Table 1 and Figure 1). According to the study of Alqutob et al. [10], by April of 2020, a total of 389 patients were confirmed to be positive for corona in Jordan. Increased Number of patient's cases was reported in April (970) patients.

We showed in Table 2 the trends of distributions of corona cases. These distribution trends were placed in the following ratios: ratio of suspected to total, ratios of confirmed to suspected, and ratio of confirmed to total. From March to July, the ratio of suspected to total was continuously decreased from $85 \%$ to $50 \%$.
Then, it was increased to up 65\% in August and September. This is plausibly due to increased awareness of public to visit the corona clinics to check their status. In August and September, we observed increased ratios, which may reflect a fluctuation in the perception of people about the corona as a conspiracy theory [11]. This theory was adopted and impacted people in Jordan. It was also interesting to find increasing ratios of confirmed to suspected from March to July, and this ratio was decreased in August and September. It was also observed that the ratio of confirmed to total was increasing from March to July, and then it was decreasing in August and September. We think that there had been some news in press that COVID-19 pandemic is going to disappear in Summer months due to increased temperatures which has impacted the perception of people regarding the disease.

Table 2: Trends of distribution of cases with corona virus.

\begin{tabular}{|c|c|c|c|}
\hline Month & Ratio of suspected to total & Ratio of confirmed to suspected & Ratio of confirmed to total \\
\hline March & $85 \%$ & $17 \%$ & $15 \%$ \\
\hline April & $76 \%$ & $31 \%$ & $24 \%$ \\
\hline May & $68 \%$ & $49 \%$ & $33 \%$ \\
\hline June & $51 \%$ & $89 \%$ & $49 \%$ \\
\hline July & $50 \%$ & $98 \%$ & $50 \%$ \\
\hline August & $64 \%$ & $56 \%$ & $36 \%$ \\
\hline September & $65 \%$ & $54 \%$ & $35 \%$ \\
\hline
\end{tabular}

\section{Conclusion}

The present study showed that during the period between March and April, corona clinics received a total of 3416 patients of whom 2294 cases were suspected to have corona virus, and a total of 1122 cases were confirmed by PCR. Cases followed similar trends in the frequency of corona virus from March to July. In August and September, changes in trends occurred which may be due to the impact of media in which it was perceived that the COVID-19 pandemic is going to end during summer months due to increased temperature degrees.

\section{References}

1. Ashour HM, Elkhatib WF, Rahman MM, Elshabrawy HA (2020) Insights into the recent 2019 novel coronavirus (Sars-coV-2) in light of past human coronavirus outbreaks. Pathogens 9(3): 186.

2. Zhang T, Wu Q Zhang Z (2020) Probable pangolin origin of SARS-CoV2 associated with the COVID-19 Outbreak. Curr Biol 30(7): 1346-1351.

3. Lai CC, Shih TP, Ko WC, Tang HJ, Hsueh PR (2020) Severe acute respiratory syndrome coronavirus 2 (SARS-CoV-2) and coronavirus disease-2019 (COVID-19): the epidemic and the challenges. Int J Antimicrob Agents 55: 105924.

4. Rabi FA, Al Zoubi MS, Al-Nasser AD, Kasasbeh GA, Salameh DM (2020) Sarscov-2 and coronavirus disease 2019: what we know so far. Pathogens 9: 231. 
5. Sohrabi C, Alsafi Z, O’Neill N, Khan M, Kerwan A, et al. (2020) World Health Organization declares global emergency: a review of the 2019 novel coronavirus (COVID-19). Int J Surg 76: 71-76.

6. (2020) World Health Organization. WHO Europe Coronavirus Disease (COVID-19) Outbreak - WHO Announces COVID-19 Outbreak a Pandemic.

7. (2020) Centers for Disease Control and Prevention. Symptoms of COVID-19.

8. Lupia T, Scabini S, Mornese Pinna S, Di Perri G, De Rosa FG, et al. (2020) 2019 novel coronavirus (2019-nCoV) outbreak: a new challenge. J Glob Antimicrob Resist 21: 22-27.

\section{ISSN: 2574-1241}

DOI: $10.26717 /$ BJSTR.2020.31.005140

Abdallah Mherat. Biomed J Sci \& Tech Res

(C) This work is licensed under Creative

Submission Link: https://biomedres.us/submit-manuscript.php
9. (2020) Johns Hopkins University. COVID-19 dashboard by the Center for Systems Science and Engineering (CSSE) at Johns Hopkins University (JHU).

10. Alqutob R, Al Nsour M, Tarawneh MR, Ajlouni M, Khader Y, et al. (2020) COVID-19 Crisis in Jordan: Response, Scenarios, Strategies, and Recommendations. JMIR public health and surveillance 6(3): e19332.

11. https://theconversation.com/coronavirus-and-conspiracies-how-thefar-right-is-exploiting-the-pandemic-145968.

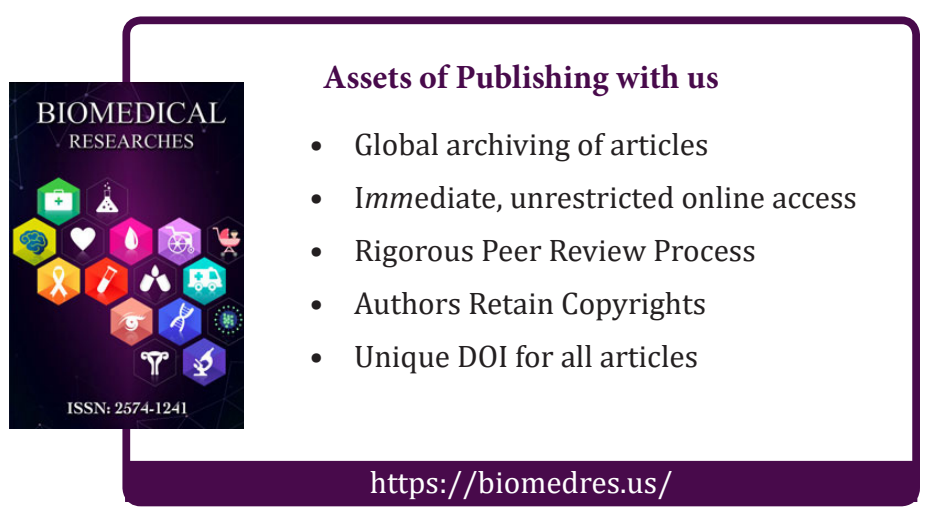

